\title{
ATP release and purinergic signaling: a common pathway for particle-mediated inflammasome activation
}

\author{
N Riteau ${ }^{1,3}$, L Baron ${ }^{1,3}$, B Villeret ${ }^{1}$, N Guillou ${ }^{1}$, F Savigny ${ }^{1}$, B Ryffel $^{1}$, F Rassendren ${ }^{2}$, M Le Bert ${ }^{1}$, A Gombault ${ }^{1,3}$ and I Couillin ${ }^{*, 1,3}$
}

Deposition of uric acid crystals in joints causes the acute and chronic inflammatory disease known as gout and prolonged airway exposure to silica crystals leads to the development of silicosis, an irreversible fibrotic pulmonary disease. Aluminum salt (Alum) crystals are frequently used as vaccine adjuvant. The mechanisms by which crystals activate innate immunity through the Nlrp3 inflammasome are not well understood. Here, we show that uric acid, silica and Alum crystals trigger the extracellular

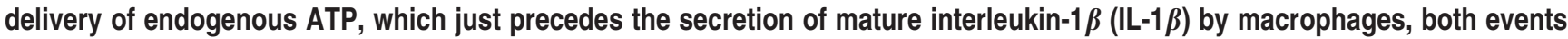
depending on purinergic receptors and connexin/pannexin channels. Interestingly, not only ATP but also ADP and UTP are involved in IL-1 $\beta$ production upon these NIrp3 inflammasome activators through multiple purinergic receptor signaling. These findings support a pivotal role for nucleotides as danger signals and provide a new molecular mechanism to explain how chemically and structurally diverse stimuli can activate the Nlrp3 inflammasome.

Cell Death and Disease (2012) 3, e403; doi:10.1038/cddis.2012.144; published online 11 October 2012

Subject Category: Immunity

Endogenous or environmental particulate dangers trigger innate immunity through assembly of the NIrp3 inflammasome, an intracellular molecular platform which under activation allows the cleavage of the potent pro-inflammatory cytokine interleukin-1 $\beta$ (IL-1 $\beta)$. Numerous studies showed that a first signal triggers synthesis of pro-IL-1 $\beta$ and NIrp3 by transcriptional induction, whereas a second stimulus leads to inflammasome oligomerization, caspase-1 auto-activation, caspase-1-dependent cleavage and release of the biologically active, mature IL-1 $\beta$. This second signal may be triggered by a group of chemically and biologically unrelated molecules such as pathogen-associated molecular patterns (PAMPs), toxins or danger-associated molecular patterns (DAMPs). DAMPs originate from environmental pollutants such as silica and asbestos, ${ }^{1,2}$ from vaccines such as aluminum salt (Alum) adjuvant ${ }^{3}$ or from endogenous metabolic stresses such as high glucose, ${ }^{4}$ cholesterol, ${ }^{5} \beta$-amyloid protein, ${ }^{6}$ biglycan, ${ }^{7}$ ATP $^{8}$ and monosodium urate crystals (MSU). ${ }^{3,9}$ Several major upstream mechanisms are currently proposed for NIrp3 inflammasome activation such as membrane disruption (for bacterial toxins and soluble ATP) or internalization of particulate activators by phagocytosis. ${ }^{10}$ Extracellular ATP (eATP) or bacterial toxins lead to $\mathrm{K}^{+}$efflux and pannexin-1 (Panx-1) pore formation, both required for Nlpr3 activation. ${ }^{11}$ Phagocytosis of particles including silica, Alum, fibrilar amyloid- $\beta$ or MSU was shown to result in lysosomal destabilization/permeabilization with release of the endosomal-lysosomal protease cathepsin B into the cytoplasm $^{2,6}$ and/or to mediate reactive oxygen species (ROS) driven activation.

We hypothesized that eATP release from stimulated cells and further purinergic signaling may be a corner stone of NIrp3 inflammasome activation pathway. ATP signaling is emerging as an important mechanism to control various cell functions. ${ }^{12}$ Cellular stimulation triggers ATP release and subsequently activation of purinergic receptors (P2X or $\mathrm{P} 2 \mathrm{Y}$ receptors) at the cell surface (autocrine activation) and/or in adjacent cells (paracrine activation), thereby regulating or modulating cellular functions in particular immunity. Essentially all cells are able to release nucleotides nevertheless the mechanisms of nucleotide release in epithelia, endothelial cells or other non-excitable cells are poorly understood. ${ }^{12,13}$ After release, eATP interacts with specific purinergic receptors or is degraded via different ecto-ATPases to di- and monophosphates and then to adenosine, ATP or its metabolites being able to signal through different purinergic receptors (P2X, P2Y or adenosine $\mathrm{P} 1$ receptors). ${ }^{14}$ In pathological conditions, high level of ATP is released from necrotic cells and acts as a pro-inflammatory danger signal, activating the NIrp3 inflammasome through binding to the ionotropic receptor $\mathrm{P} 2 \times 7 .{ }^{15}$

Here, for the first time we provide evidence that uric acid, silica and aluminum particles induce the active release of

\footnotetext{
${ }^{1}$ University of Orleans, CNRS, UMR7355, INEM, Transgenose Institute, Orleans, France and ${ }^{2}$ IGF, CNRS UMR 5203, INSERM U661, University of Montpellier I \& II, Montpellier, France

${ }^{*}$ Corresponding author: I Couillin, Experimental and Molecular Immunology and Neurogenetics, UMR7355, 3B rue de la Férollerie, Orleans 45071, France. Tel: + 332382554 43; Fax: + 3323825 79 79; E-mail: couillin@cnrs-orleans.fr

${ }^{3}$ These authors contributed equally to this work.

Keywords: ATP; danger signal; inflammasome; P2R; NLR

Abbreviations: ATP, adenosine triphosphate; IL-1 $\beta$, interleukin-1 beta; NLR, Nod-like receptor; MSU, monosodium urate crystal; PAMPs, pathogen-associated molecular patterns; DAMPs, danger-associated molecular patterns; ROS, reactive oxygen species

Received 14.2.12; revised 03.9.12; accepted 06.9.12; Edited by A Finazzi-Agró
} 
intracellular ATP to the outside of human macrophages, depending in some extent to functional P2X7 receptor and connexin/pannexin channels. Moreover, we show a strong correlation between ATP release and secretion of mature IL$1 \beta$ after stimulation of primed human macrophages. In addition, crystals exposure to primed murine macrophages leads to maturation of IL- $1 \beta$ that highly depends on purinergic receptor signaling with the involvement of multiple autocrine purinergic receptor loops.

We identify a new mechanism for crystals-mediated NIrp3 inflammasome activation and mature $\mathrm{IL}-1 \beta$ release through multiple purinergic receptors and connexin/pannexin pore activation. We provide a link between ATP- and crystalsmediated inflammasome activation demonstrating that crystals act through ATP release to induce inflammasome activation and propose a new hypothesis allowing understanding how such a variety of activators can activate NIrp3 inflammasome.

\section{Results}

MSU, silica or Alum crystals trigger active ATP release and IL-1 $\beta$ secretion in human macrophages. Recently, we showed that stimulation of lung epithelial cells with bleomycin, a cytotoxic agent that causes DNA damage, leads to a rapid release of ATP partly dependent on functional P2X7 receptor and Panx-1 pore formation. ${ }^{16}$ Since activated or stressed cells were shown to release ATP, we investigate whether crystals or particles known as activators of the NIrp3 inflammasome may act through ATP leakage to trigger IL-1 $\beta$ maturation. ${ }^{13,17}$ We observed that MSU or silica crystals cause active ATP release by pulmonary epithelial cell lines, which depends on purinergic receptors and pannexin/connexin channels but not mature IL- $1 \beta$ production (data not shown). To determine whether particulate NIrp3 inflammasome activators are able to trigger the release of endogenous ATP by the macrophage lineage, the human monocyte/macrophage cell line THP-1 was stimulated with MSU crystals during various times. Luciferase ATP assays revealed that MSU crystals trigger the release of ATP by human macrophages, which peaks at $2 \mathrm{~h}$ (Figure 1a). Since the extracellular accumulation of ATP reflects the balance between ATP release by cells and ATP hydrolysis by ectonucleotidases, ${ }^{18}$ we used the ecto-ATPase inhibitor ARL67156 to limit ATP catabolism. In the presence of ARL67156, the levels of ATP detected in the different supernatants increased up to sixfold (Figure 1b). From the same macrophage culture and at a given end time point, we co-analyzed ATP release and mature IL-1 $\beta$ in the presence of ARL67156 and observed that ATP release is strongly correlated with IL-1 $\beta$ secretion (Figure 1c). Hence, ATP release induced by MSU or Alum is transient and precedes sustained IL-1 $\beta$ production by the same macrophages. After silica stimulation, responses were delayed and we did not observe the peak of ATP release even after $6 \mathrm{~h}$. In contrast allopurinol crystals, known to fail in activating the NIrp3 inflammasome, ${ }^{9}$ induced neither ATP release nor IL-1 $\beta$ secretion (Figure 1c). Importantly, cell death measured by MTT was minimal, suggesting that ATP release is not the consequence of any macrophage death (Figure 1d). These data suggest that IL-1 $\beta$ secretion is a consequence of ATP leakage induced by particulate NIrp3 activators.

Phagocytosis or cystein proteases inhibition blocks both ATP release and IL-1 $\beta$ production in human macrophages. Particle phagocytosis is known to be
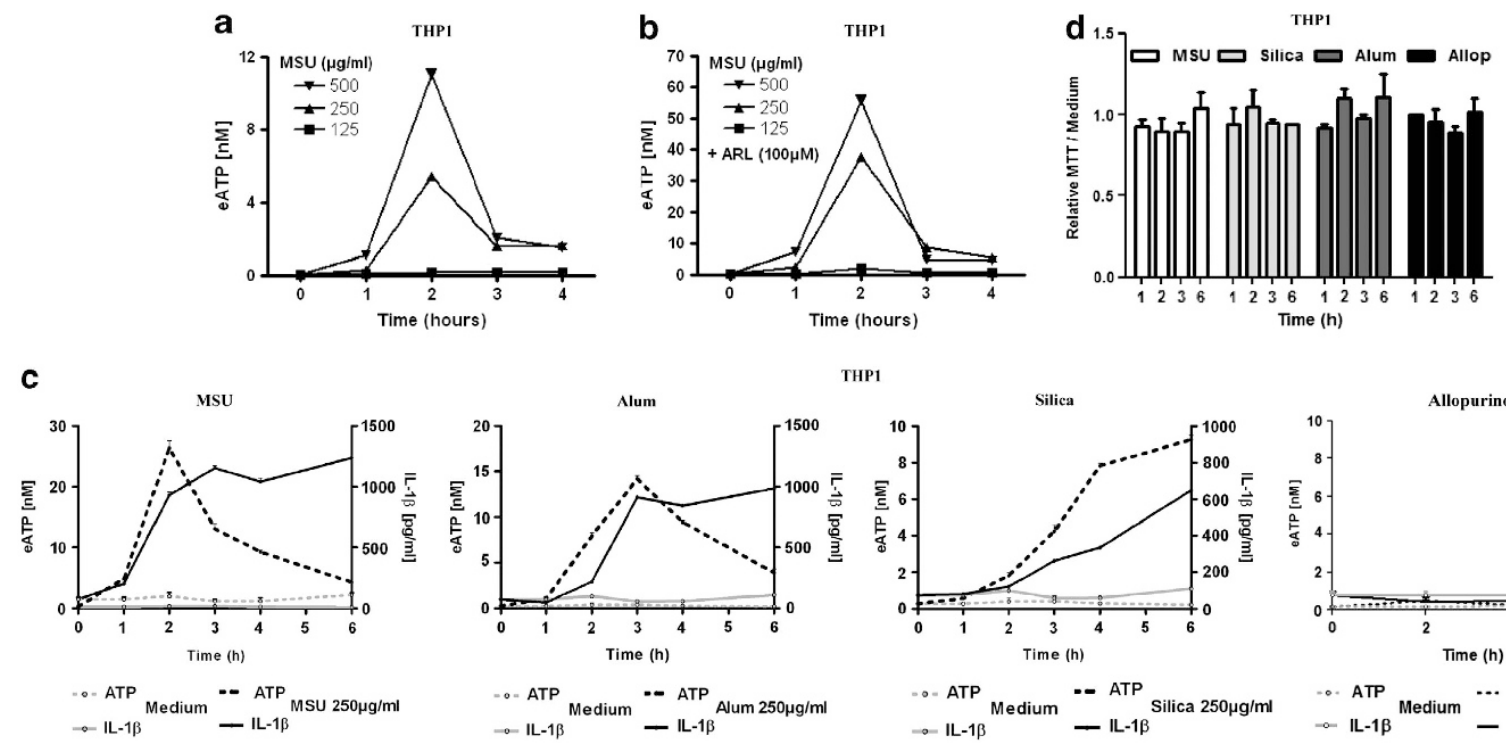

THP1

$\rightarrow$ IL-1 $1 \beta$
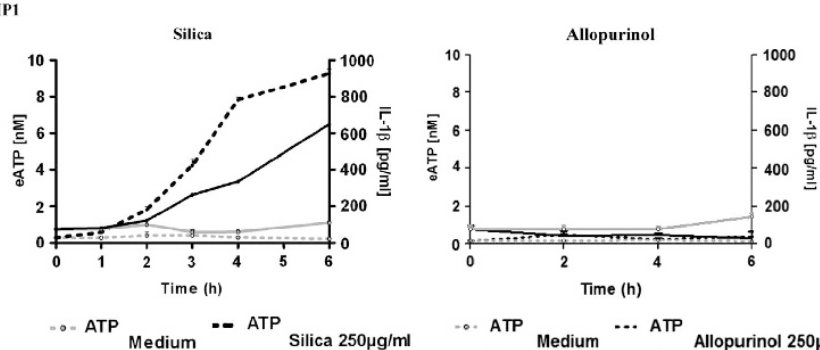

$\therefore$ IL-1 ${ }^{\text {Medium }}-\mathrm{LL}-1 \beta$

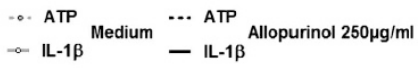

Figure 1 MSU, silica or Alum crystals trigger active release of ATP by human macrophages. PMA-primed THP-1 cells incubated with MSU crystals release ATP in the supernatant that peaks after $2 \mathrm{~h}$ and rapidly return to baseline (a). Higher concentrations were obtained using the ecto-ATPase inhibitor ARL67146 (ARL) to preserve ATP (b). In the presence of ARL67146, there is a strong correlation between MSU, silica and Alum-induced ATP release and IL-1 $\beta$ production, whereas allopurinol crystals do not induce ATP release or IL-1 $\beta$ secretion (c). MTT assay revealed no significant change in cell viability at studied time points (d). Data are representative of three independent experiments and are expressed as mean values \pm S.D. 
essential for inflammasome activation and mature $\mathrm{IL}-1 \beta$ production. ${ }^{2}$ However, cytoskeleton is not necessary for IL$1 \beta$ secretion. ${ }^{3}$ Here, we show that ATP leakage is completely impaired by cytochalasin $D$, which inhibits actin polymerization, demonstrating that ATP release is a physiologic process needing particle phagocytosis by human macrophages (Figure 2a). Moreover, we confirmed that cytochalasin D abrogates IL- $1 \beta$ production (Figure $2 \mathrm{~b}$ ). Importantly, cysteine proteases, for example, cathepsin $B$ and $L$, were shown to be involved in NIrp3 activation in response to particles. ${ }^{2,5} \mathrm{We}$ show here that E-64d, a broad inhibitor of cysteine proteases is able to dramatically reduce ATP release and IL-1 $\beta$ secretion (Figure $2 b$ ) whereas the control acidic protease inhibitor pepstatin A had no effect (Figures $2 a$ and $b$ ). In addition, cathepsin B specific inhibitor Ca074-Me dose dependently reduced eATP and IL- $1 \beta$ production induced by silica, suggesting a specific role for cathepsin $B$ (Figure 2c). Altogether, these data suggest that particle internalization/lysosome destabilization with lysosomal cathepsin leakage precedes ATP release and IL-1 $\beta$ production by human macrophages.

Purinergic signaling and pannexin/connexin hemichannels are required for ATP release and IL-1 $\beta$ secretion in human macrophages. We then investigated the mechanisms of particle-induced ATP release leading to IL-1 $\beta$ secretion. Since P2X7 receptor and Panx-1 hemichannel were involved in ATP release from different cell types after stress or activation, we next investigated their role in a particle-induced context. ${ }^{19}$ Three potential mechanisms for regulated nucleotide release after cell stimulation, exocytosis, blebbing or passage via a plasma membrane channel may be considered. ${ }^{14}$ We focused on channel(s) that have been shown to mediate nucleotide release and among them the connexin and pannexin family channels. ${ }^{20}$ Connexins were first shown to form gap junctions between cells, mediating intercellular communication, but emerging literature reports direct hemichannel activity, ${ }^{21}$ hence able to act similarly as pannexin hemichannels which upon activation mediate molecule and ion transfers between intracellular and extracellular compartments. ${ }^{20,22}$ Using pharmacological inhibitors, we show that the connexin/pannexin channel blocker carbenoxolone (CBX) and the connexin channel blocker flufenamic acid (FFA) reduced significantly both ATP and $\mathrm{IL}-1 \beta$ release, indicating that connexin and/or pannexin hemichannels are involved in ATP release and IL-1 $\beta$ production (Figures $3 a$ and $b$ ). Moreover, specific inhibition of the P2X7 receptor by $\mathrm{A} 740003^{23}$ at $10 \mu \mathrm{M}$ led to partial inhibition of ATP release and IL-1 $\beta$ production by Alum but not by silica, whereas higher concentrations were efficient in both ATP and IL-1 $\beta$ releases (Figures $3 a$ and b). In conclusion, particles induce $\mathrm{P} 2 \mathrm{X} 7$ receptor-dependent ATP release through connexin and/or pannexin channels leading to mature $\mathrm{IL}-1 \beta$ secretion in the same extent.

IL-1 $\beta$ production by murine macrophages depends on cysteine proteases, purinergic receptors and pannexin/ connexin hemichannels. Conversely to THP-1 human monocyte/macrophage cell line, we could not measure significant ATP increase in the supernatant of stimulated murine bone marrow-derived macrophages (BMDM) or dendritic cells (BMDC) even adding the ecto-ATPase
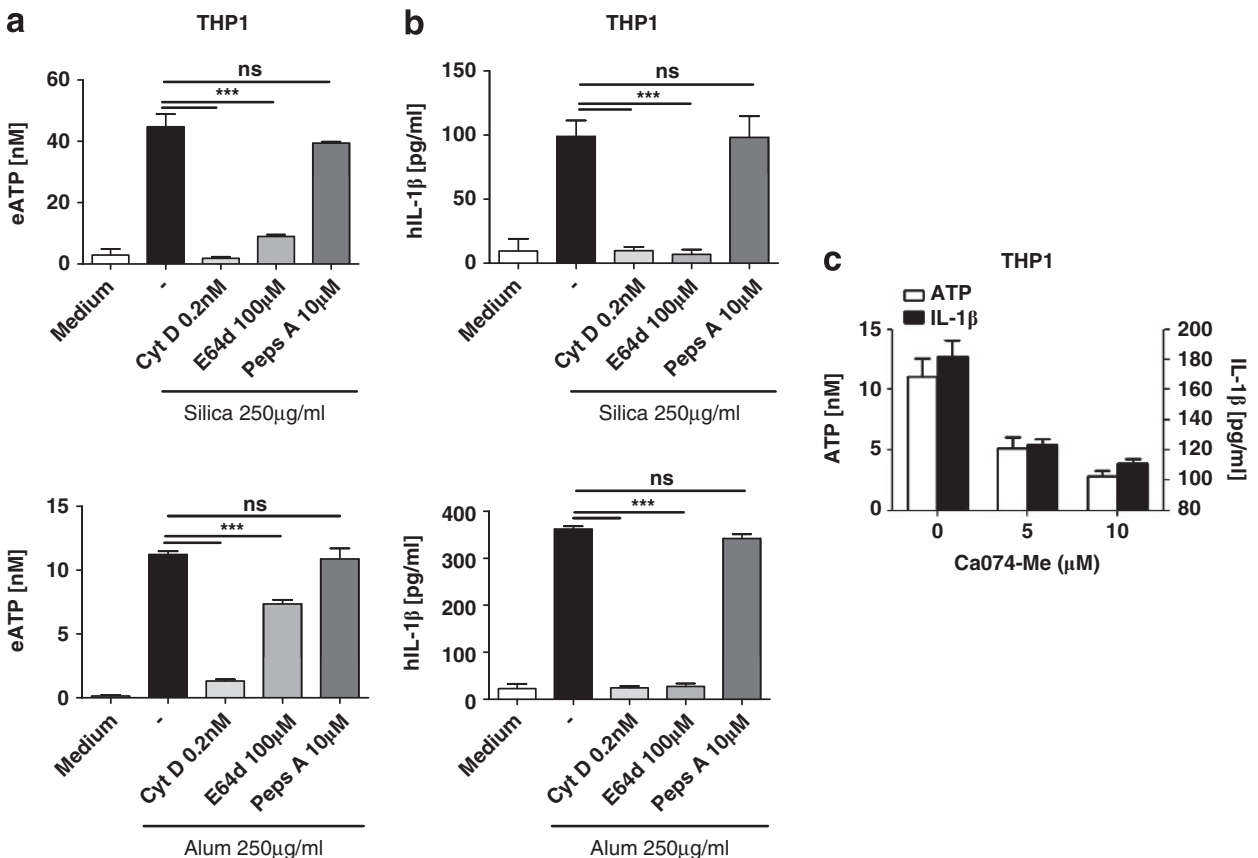

Ca074-Me $(\mu \mathrm{M})$

Figure 2 Phagocytosis or cysteine proteases inhibitors block both IL-1 $\beta$ production and ATP release by human macrophages. PMA-primed THP1 cells were incubated with silica or Alum salt crystals for $3 \mathrm{~h}$. Phagocytosis inhibitor cytochalasin D (Cyt D) and cysteine proteases inhibitor E-64d but not acidic protease inhibitor pepstatin A (Peps A) were able to strikingly decrease both silica- or Alum-induced ATP release (a) and IL-1 $\beta$ production (b) in PMA-primed THP-1 cells. Cathepsin B specific inhibitor Ca074-Me dose dependently reduced EATP and IL-1 $\beta$ production induced by silica (c). Data are representative of three independent experiments and are expressed as mean values \pm S.D. $\left({ }^{* * *} P<0.001 ;\right.$ ns, non-significant) 

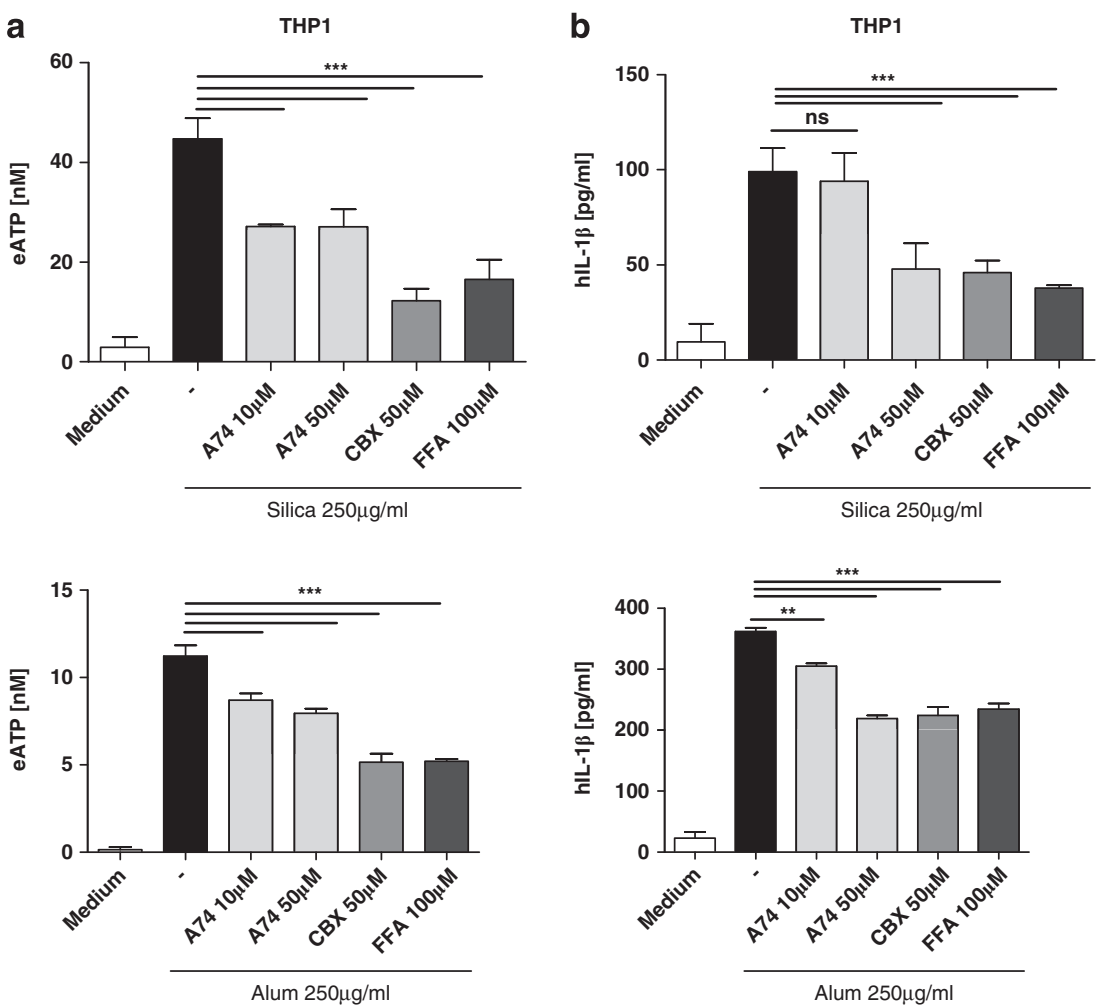

Figure 3 P2X7 receptor or pannexin/connexin hemichannel involvement in ATP release and IL-1 $\beta$ secretion in human macrophages. PMA-primed THP-1 cells were incubated with silica or Alum salt crystals. Connexin/pannexin channel blocker carbenoxolone (CBX) and connexin channel blocker flufenamic acid (FFA) significantly reduced both ATP and IL-1 $\beta$ release induced by silica and Alum (a and $\mathbf{b})$. Specific inhibition of the P2X7 receptor with $10 \mu \mathrm{M}$ A740003 leads to partial inhibition of ATP release without inhibition of IL-1 $\beta$ production, whereas higher concentrations are efficient in both ATP release and IL-1 $\beta$ production but might be non-specific (a and $\mathbf{b}$ ). Data are representative of three independent experiments and are expressed as mean values \pm S.D. ( ${ }^{\star \star} P<0.01 ;{ }^{* \star *} P<0.001$; ns, non-significant)

inhibitor ARL67156. This may be due to fastest ATP degradation by these cells and/or to limitation of our measurement assay. Using cytochalasin $\mathrm{D}$, we first confirmed that MSU, silica or Alum salt crystal-induced IL-1 $\beta$ secretion by murine macrophages required phagocytosis (Supplementary Figures $1 \mathrm{a}$ and $\mathrm{b}$ ) whereas allopurinol crystals did not induce IL-1 $\beta$ (Supplementary Figure 1c). Conversely, ATP- or nigericin-induced IL- $1 \beta$ secretion was not affected by cytochalasin D confirming cytochalasin D abrogates particle phagocytosis but not P2X7 receptor and/or pannexin channel activities (Supplementary Figure 1d). Since a role for cathepsin B in crystal-induced inflammasome activation is still controversial, we analyzed the effect of protease inhibitors. The cysteine cathepsin and calpain inhibitors (E64d, Z-FA-FMK), the cysteine cathepsin $B$ inhibitor (Ca074-Me) but not the cysteine cathepsin L inhibitor or the aspartic acid protease cathepsin $D$ inhibitor (pepstatin A) dose dependently decreased IL-1 $\beta$ upon silica and Alum crystals (Supplementary Figures $1 \mathrm{a}$ and $\mathrm{b}$ ). In addition, macrophages from cathepsin B-deficient mice stimulated with MSU, silica or Alum crystals presented a significant decrease of IL-1 $\beta$ (Supplementary Figure 1e). These data indicate that mature IL- $1 \beta$ secretion depends at least partially on the cysteine protease cathepsin $B$ but not on the cysteine protease cathepsin $L$ and the aspartic acid protease cathepsin D. Moreover, the P2X7 receptor specific inhibitor A740003, the broad-spectrum P2 receptor inhibitor
oATP or the phospholipase C inhibitor U73122 blocking signaling through the P2Y1-like subfamily (P2Y1, P2Y2, P2Y4, P2Y6, P2Y11) strikingly decreased or suppressed IL$1 \beta$ production upon MSU, silica or Alum crystals in murine BMDM (Figure 4a) and BMDC (not shown) in a dosedependent manner. CBX and FFA were also efficient in inhibiting IL-1 $\beta$ secretion upon silica or Alum in BMDM (Figure 4b). The use of oATP, A740003 or CBX blocked crystal-induced IL- $1 \beta$ but not TNF- $\alpha$ production by BMDM (Supplementary Figure 2). These data demonstrate a specific effect of purinergic signaling and connexin/pannexin inhibition in NIrp3 inflammasome activation pathway without toxic effect. Western blotting analysis confirmed that inhibition of purinergic signaling or connexin activity decreased amount of secreted $17 \mathrm{kDa}$ mature IL- $1 \beta$ produced by BMDM upon silica or Alum particles stimulation (Figure 4c). Altogether, purinergic receptors and connexin/pannexin channels are required for IL-1 $\beta$ production by the three tested NIrp3 inflammasome activators.

Single deletion in $\mathrm{P} 2 \mathrm{X} 7, \mathrm{P} 2 \mathrm{X} 4$ or $\mathrm{P} 2 \mathrm{Y} 2$ receptor does not affect IL-1 $\beta$ production by murine macrophages. In an attempt to better delineate particle-mediated IL-1 $\beta$ production, we performed experiments with macrophages from Nlrp3 inflammasome components or for ATP purinergic receptors deficient mice. Consistent with published reports, ${ }^{1,2,9}$, IL-1 $\beta$ but not TNF- $\alpha$ secretion upon MSU, 
a
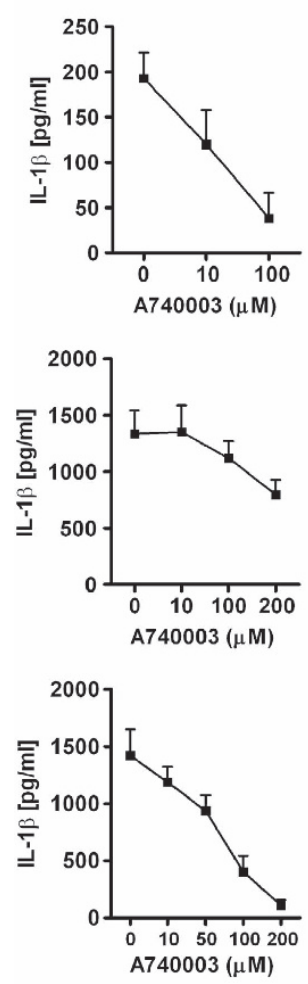

BMDM
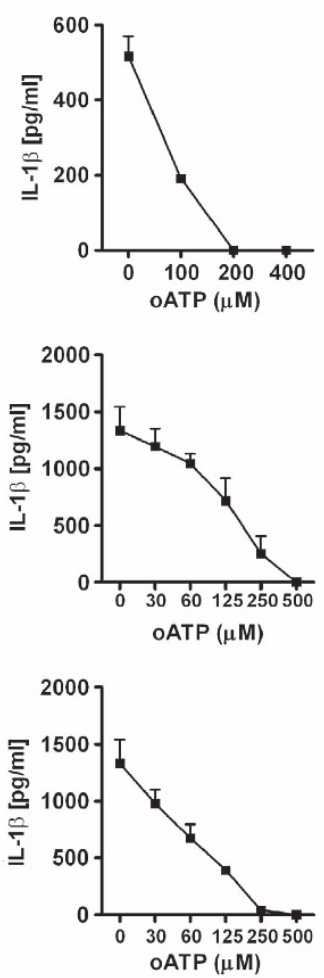
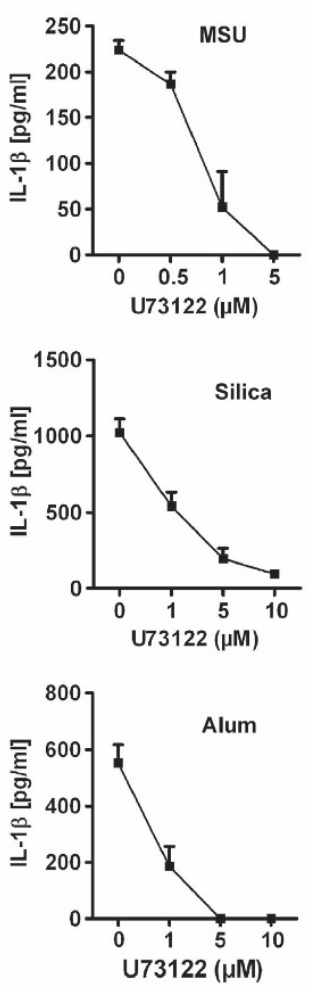

b
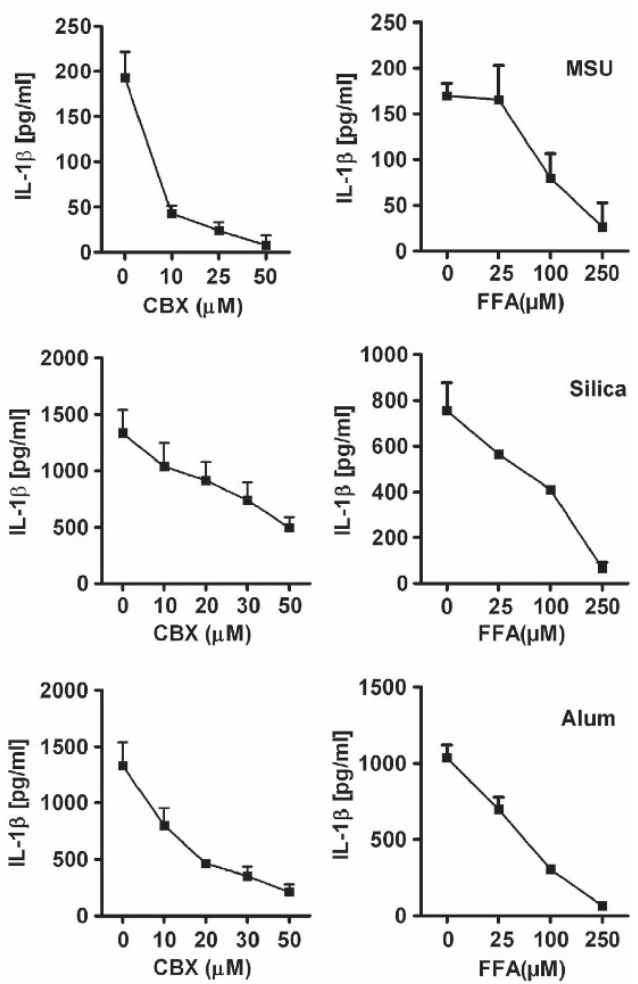

C

BMDM

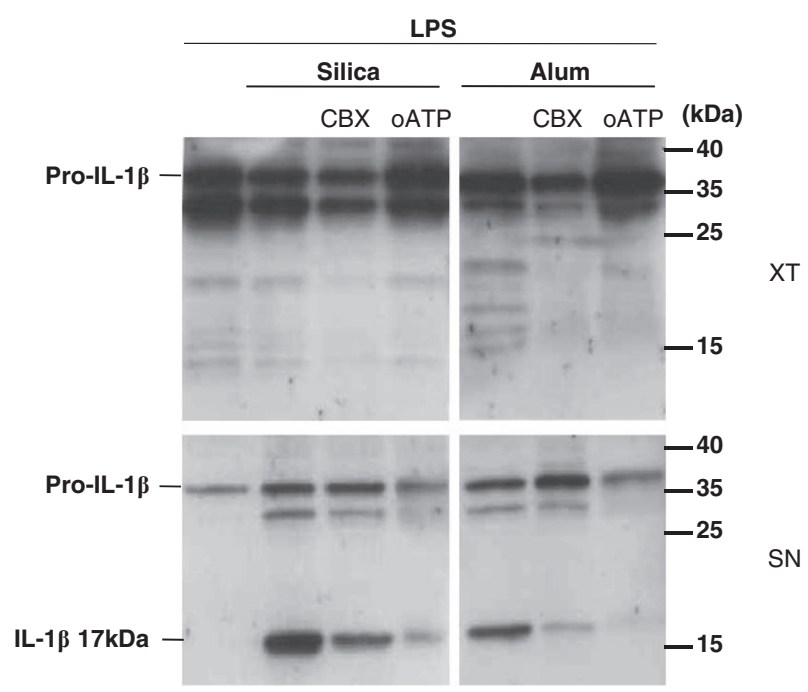

Figure 4 IL-1 $\beta$ production by murine macrophages upon MSU, silica or Alum depends on purinergic signaling and pannexin/connexin hemichannels. IL-1 $\beta$ production by LPS-primed BMDM stimulated with silica or Alum is dose dependently decreased using P2X7 inhibitor A740003 and more potently with the broad-spectrum purinergic inhibitor OATP or with the phospholipase C inhibitor U73122 blocking several P2YRs (a). The same inhibitory effect is observed with the connexin/pannexin inhibitor CBX and with the connexin channel blocker FFA (b). Western blot analysis of LPS-primed BMDM cell extracts (XT) and supernatants (SN) confirmed that oATP $(500 \mu \mathrm{M})$ or CBX (50 $\mu \mathrm{M})$ significantly decreased $17 \mathrm{kDa}$ mature IL-1 $\beta$ production in response to silica or Alum (c). Molecular weight markers are shown at the right (c). Data are representative of three independent experiments and are expressed as mean values \pm S.D.

silica or Alum, was Nlrp3 inflammasome dependent (Supplementary Figures $3 a$ and b), whereas deficiency for NIrc4 in macrophages (Supplementary Figure 3c) or dendritic cells (Supplementary Figure 3d) had no effect. In contrast, macrophages from $\mathrm{P} 2 \mathrm{X} 7$ receptor-deficient mice stimulated with MSU, silica or Alum did not present a significant decrease in IL-1 $\beta$ production (Figure 5a). As expected, $\mathrm{P} 2 \mathrm{X} 7$ receptor but not $\mathrm{P} 2 \mathrm{X} 4$ receptor, was fully required for Nlrp3 activation in response to high ATP concentrations (Figure $5 b$ ). In addition, single deletion of the ATP ionotropic 


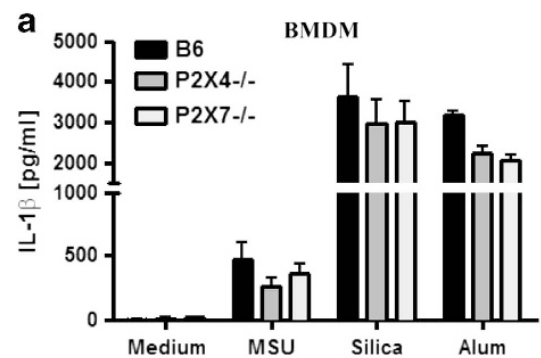

b

BMDM

C
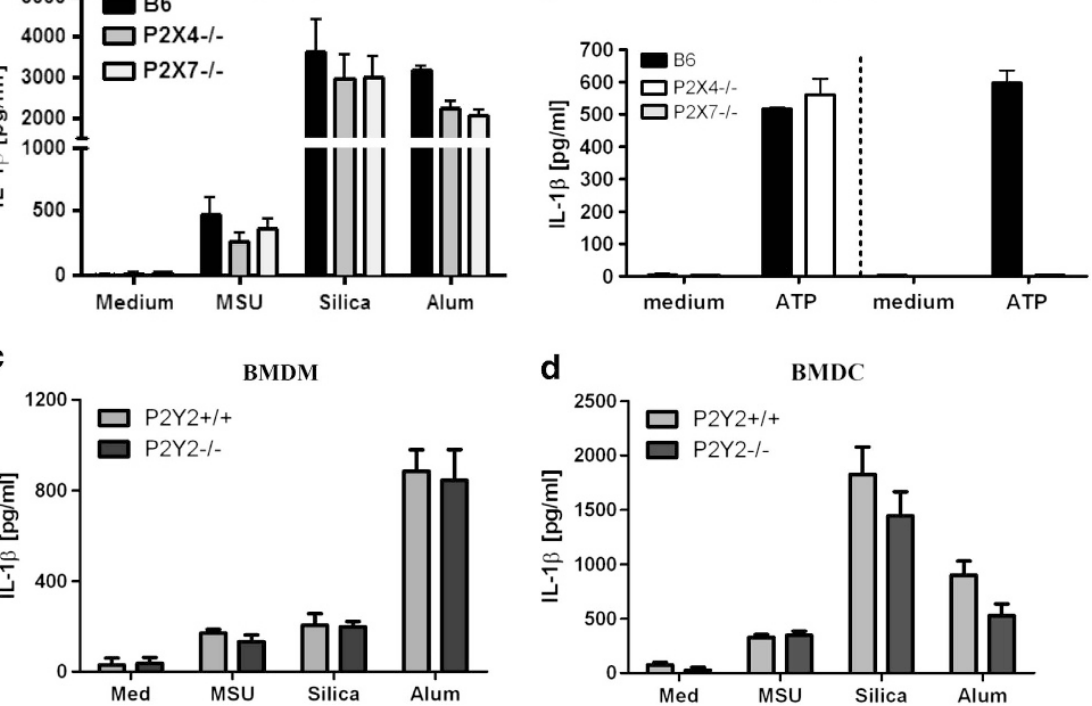

Figure 5 Single P2R deficiency does not lead to reduced IL- $1 \beta$ production. BMDM deficient for P2X7 or P2X4 receptors were LPS-primed for $3 \mathrm{~h}$ and stimulated with MSU, silica or alum for $6 \mathrm{~h} \mathrm{IL-1} \beta$ production is not significantly decreased (a). In contrast, high exogenous ATP (5 mM; $45 \mathrm{~min})$-induced IL- $1 \beta$ production is fully dependent on P2X7 but not on P2X4 receptors (b). P2Y2 receptor-deficient BMDM (c) or BMDC (d) presented no significant decrease in IL-1 $\beta$ production. Data are representative of three independent experiments and are expressed as mean values \pm S.D.

P2X4 receptor (Figure 5a) known to act together with P2X7 receptor $^{7}$ or of the ATP/UTP metabotropic P2Y2 receptor involved in cell chemotaxis in response to ATP leakage, ${ }^{24}$ did not lead to significant impairment in IL-1 $\beta$ production by BMDM (Figure 5c) or BMDC (Figure 5d). Discrepancies between strong effect of biochemical inhibitors and single gene deficiency may reflect redundancy between purinergic receptors or multiple purinergic receptors signaling.

ATP, ADP and UTP nucleotides are involved in particlemediated inflammasome activation. In order to confirm the role of ATP and purinergic signaling in microparticleinduced IL-1 $\beta$ secretion, we stimulated murine macrophages in the presence of apyrase, an ATP consuming enzyme. Figure 6a shows apyrase (grade VII that hydrolyzes ATP and ADP) abrogated silica-induced IL-1 $\beta$ secretion similarly to ATP-induced IL-1 $\beta$ whereas apyrase alone had no effect on IL-1 $\beta$ secretion and cell viability (not shown). These results demonstrate the role of ATP and/or ADP in particle-mediated IL-1 $\beta$ secretion. To further study the involvement of multiple purinergic receptors signaling in sensing NIrp3 inflammasome particulate activators, we stimulated macrophages with particles in the presence of different nucleotides or purinergic receptor agonists. Addition of $500 \mu \mathrm{M}$ ATP, UTP or ADP to LPS-primed murine macrophages did not lead alone to IL-1 $\beta$ secretion but exacerbated MSU, silica or Alum-induced production of IL-1 $\beta$ (Figure $6 \mathrm{~b}$ ). Consistently, stable ATP $\gamma \mathrm{S}$ or $A D P \beta S$ agonists were more potent than ATP or ADP to enhance particles-induced IL-1 $\beta$ production (Figure $6 b$ ). Interestingly, addition of equivalent concentrations of MeATP (P2X agonist) or UTP (P2Y agonist) were not able to induce IL- $1 \beta$ but potentiated the response to MSU or silica crystals (Figure 6c). We obtained similar results using human macrophages and smaller concentration of ATP, ATP $\gamma \mathrm{S}$,
$\operatorname{ADP}$ or $\operatorname{ADP} \beta S(1,10,50,100$ or $200 \mu \mathrm{M})$ which dose dependently increased IL-1 $\beta$ production induced by suboptimal quantities of silica or Alum whereas they had not effect alone (Figure 6d). Moreover, a small effect of UTP was observed (Figure 6d). The same results with lower concentrations of ATP, ATP $\gamma$ S, ADP or ADP $\beta$ S were obtained with murine BMDM macrophages (not shown). In addition, ADP, a specific ligand for P2Y receptors, dose dependently increased the murine macrophage response to MSU or silica further, suggesting the involvement of ADP purinergic receptors (Figure 6e). In contrast, the downstream nucleotide catabolism product adenosine inhibited MSU and silicainduced production of $\mathrm{IL}-1 \beta$ by murine dendritic cells (Figure 6f). These data demonstrate that not only ATP but also its metabolic derivative ADP or UTP play an active role in inflammasome activation in response to microparticles. In conclusion, purinergic signaling by both $\mathrm{P} 2 \mathrm{X}$ and P2Y receptors in the context of particle-induced cell response is necessary for efficient IL-1 $\beta$ production by the NIrp3 inflammasome.

\section{Discussion}

Here, we provide a link between ATP- and crystal-mediated inflammasome activation, demonstrating that crystals act through ATP release to induce IL- $1 \beta$ maturation. Large amount of eATP $(5 \mathrm{mM})$ was identified as a powerful second signal inducing pro-IL-1 $\beta$ processing into mature IL-1 $\beta$ in a two-step model for IL- $1 \beta$ secretion by murine ${ }^{25}$ and human macrophages ${ }^{9}$ through P2X7 receptor signaling. ${ }^{26}$ In contrast, primary human monocytes were shown to require only one signal since exogenous LPS was sufficient to induce secretion of mature IL-1 $\beta$, although exogenous ATP strongly accelerates IL-1 $\beta$ processing and secretion. ${ }^{27,28}$ In addition in 


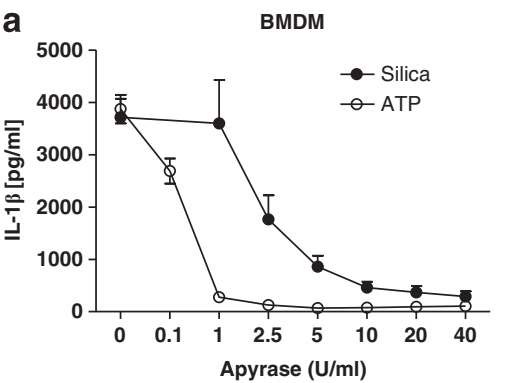

BMDM
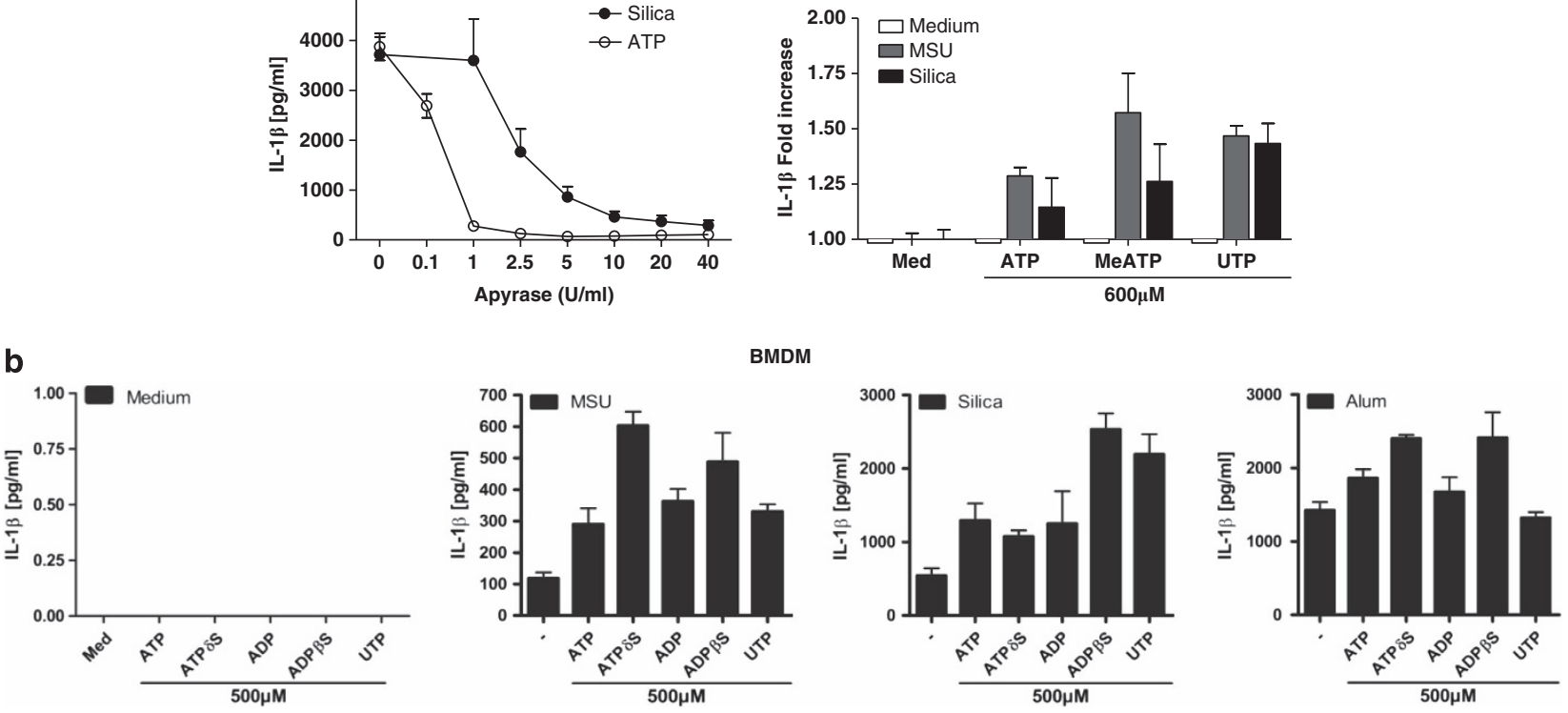

d

THP1

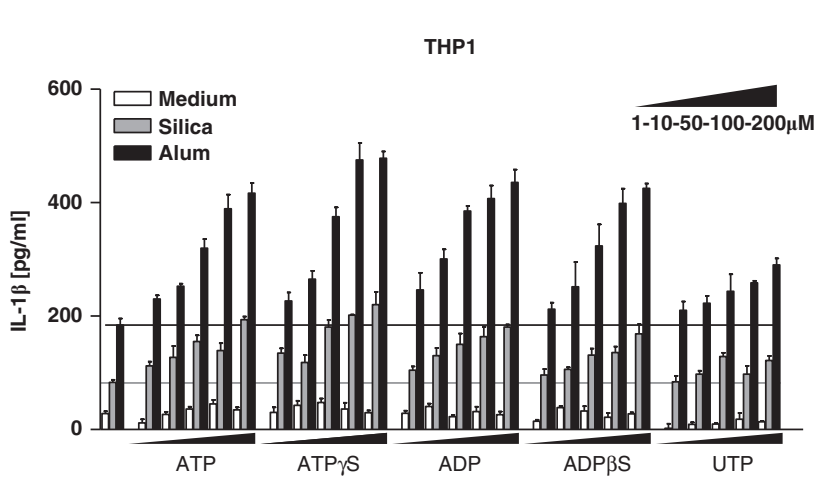

e

BMDM
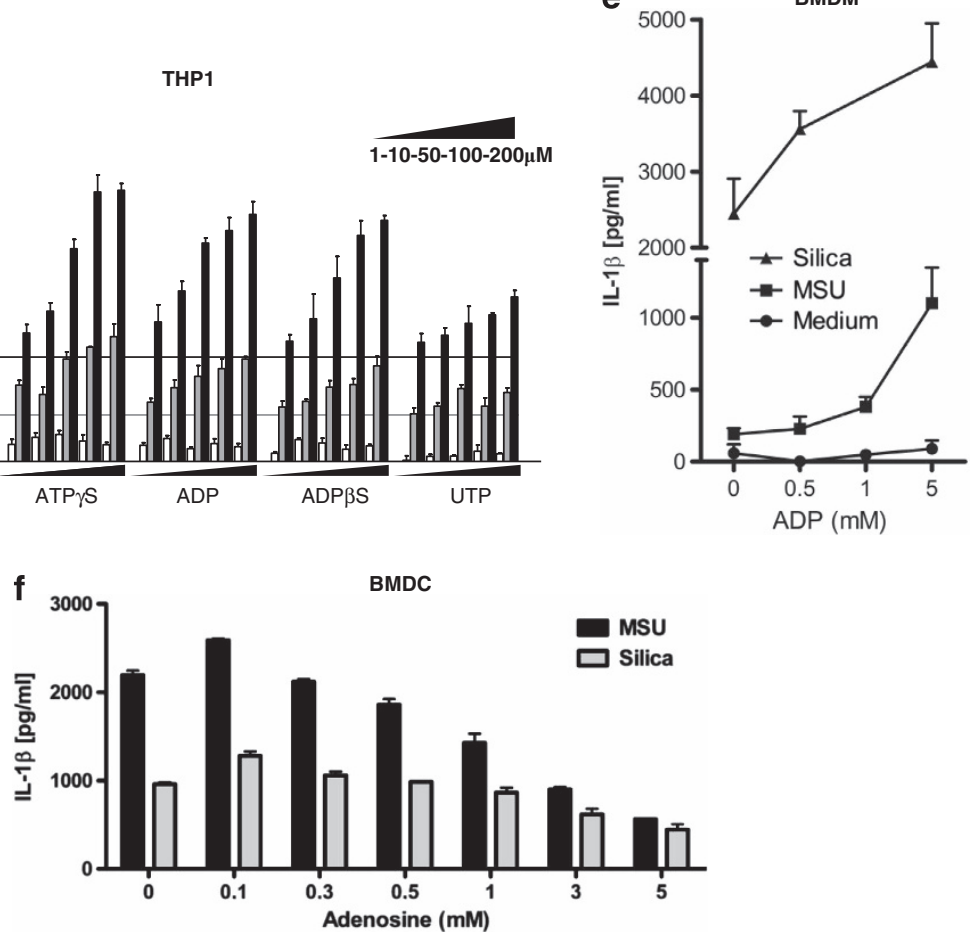

Figure 6 Involvement of ATP, ADP and UTP nucleotides in crystal-induced inflammasome activation. IL-1 $\beta$ secretion by LPS-primed murine BMDM stimulated for $6 \mathrm{~h}$ with silica crystals $(250 \mu \mathrm{g} / \mathrm{ml})$ or ATP $(5 \mathrm{mM})$ was dose dependently abrogated in the presence of apyrase (a). LPS-primed murine BMDM stimulated with $500 \mu \mathrm{M}$ of ATP, ADP or stable derivatives, respectively, ATP $\gamma$ S and ADP $\beta$ S, do not lead alone to production of IL-1 $\beta$. However, they strongly enhance IL-1 $\beta$ production induced by particles (b). Similarly, $600 \mu \mathrm{M}$ of P2X receptor agonist MeATP or P2YRs agonist UTP are able to increase the IL-1 $\beta$ production from 25 to $50 \%$ (c). The same synergistic effects of ATP, ATP $\gamma$ S, ADP and ADP $\beta$ S are observed in PMA-primed THP1 stimulated with alum $(125 \mu \mathrm{g} / \mathrm{ml})$ or silica $(250 \mu \mathrm{g} / \mathrm{ml})$ dose dependently $(1,10,50,100$ or $200 \mu \mathrm{M})$ (d). UTP also slightly increased IL-1 $\beta$ production (d). ADP up to $5 \mathrm{mM}$ is not sufficient alone for IL-1 $\beta$ maturation, but it highly exacerbates MSU or silica-induced IL- $1 \beta$ production by LPSprimed BMDM (e). By contrast, adenosine dampens MSU or silica-induced IL-1 $\beta$ production by BMDC (f). Data are representative of two to three independent experiments and are expressed as mean values \pm S.D.

human monocytes several PAMPs and one DAMP were shown to trigger both the first and the second signals with extracellular release of endogenous ATP acting on the P2X7 receptor in an autocrine loop, triggering mature $\mathrm{IL}-1 \beta$ secretion in a one-step model of inflammasome activation. ${ }^{29}$ Here, we demonstrate that in the presence of the first signal, MSU, silica or Alum salt crystals trigger the second one leading to mature IL-1 $\beta$ production by human macrophages 
through ATP release and subsequent purinergic signaling. Importantly, allopurinol crystals known to fail in NIrp3 inflammasome activation ${ }^{9}$ are unable to trigger ATP release.

We show that OATP recognized as a broad inhibitor of P2X and P2Y receptor was able to prevent crystal-induced maturation of $\mathrm{IL}-1 \beta$ by murine or human macrophages, highlighting the importance of the P2 purinergic receptor family. Moreover, crystal-induced secretion of mature IL-1 $\beta$ was abrogated by ATP/ADP consuming enzyme apyrase confirming the role of ATP and purinergic signaling in inflammasome activation. Nevertheless, P2X7 receptor deficiency in murine macrophages does not change the cell capacity to produce IL-1 $\beta$ albeit high concentrations of the P2X7 receptor inhibitor A740003 were able to severely impair the cytokine production, suggesting the involvement of other P2 receptors. Several works have reported that blocking or deleting P2X7 receptor did not affect $\mathrm{MSU}^{9}{ }^{9}$ silica ${ }^{15}$ or Alum salt ${ }^{3}$ crystals-induced IL-1 $\beta$ production, supporting a role for other purinergic receptors in non-pathologic conditions. In the opposite, Alzheimer disease-related amyloid- $\beta$ protein aggregates were shown to promote IL- $1 \beta$ release through P2X7 receptor-mediated ATP release. ${ }^{30}$ Similarly single deficiency in P2X4 or P2Y2 receptors had no major effects on mature IL-1 $\beta$ production. Even if further experiments need to be performed to better decipher the role of each receptor, our data suggest the involvement of multiple purinergic signaling.

Nlrp3 inflammasome activation by large amount of ATP $(5 \mathrm{mM}, 30 \mathrm{~min})$ in the presence of LPS constitutes an in vitro model as prolonged stimulation results in membrane disruption and cell death underlying the pathological impact of high ATP levels. Importantly, we demonstrate that mild doses of ATP, and unexpectedly also of ADP and UTP, albeit having no effect by themselves, synergize with particles for highest IL-1 $\beta$ production. These data strongly suggest that the two purinergic receptor families $\mathrm{P} 2 \mathrm{X}$ and $\mathrm{P} 2 \mathrm{Y}$ are involved since both ADP and UTP acting only on P2Y, seem to play a role. As mild doses of ATP, ADP or UTP were unable alone to promote mature IL-1 $\beta$ production, another signal triggered by crystal stimulation may be required, for example, a P2X7 receptorindependent potassium efflux. All particles affecting inflammasome activity were shown to be fully dependent on potassium efflux, suggesting a role for ionotropic P2X receptors or other potassium channels. It was shown before that not only ATP but other nucleotides such as ADP, UTP or UDP are released in the extracellular space from mechanically stressed cells, in particular endothelial and epithelial cells. ${ }^{13,31}$ These compounds may act on different purinergic receptors to generate a fine-tuned response.

In contrast to human macrophages, we were unable to detect eATP after murine macrophages stimulation by crystals. This is likely due to a higher level of ecto-ATPase activity by murine cells since we observed that exogenous ATP added to murine macrophages rapidly became undetectable in contrast to the same amount of exogenous ATP added to human macrophages. These observations suggest a local increase of ADP/AMP/adenosine and possible action on IL- $1 \beta$ production pathway. It is worth to note that the derivative compound adenosine has been shown to act as an antiinflammatory mediator and could hence counter-balance ATP/ADP activity. ${ }^{32}$
Using pharmacological inhibitors, we found that MSU, silica or Alum crystal-induced mature IL-1 $\beta$ secretion by murine or human macrophages is dependent on connexin/pannexin channels. Panx-1 hemichannel has been involved in NIrp3 inflammasome activation in response to high ATP, nigericin, maitotoxin and bacterial components. ${ }^{33-35}$ Nevertheless, a recent work using Panx-1-deficient mice observed no impact on mature IL-1 $\beta$ production upon ATP, MSU or silica particles. ${ }^{36}$ Compensation between pannexins and/or connexins able to form hemichannels may exist in classical deficient mice and conditional Panx-1 mice would be useful. The use of pharmacologic inhibitors indicates that ATP is released through pannexin/connexin hemichannels as shown elsewhere. ${ }^{36,37}$ We also show that ATP release by human macrophages depends on purinergic signaling and in particular on P2X7 receptor, suggesting the existence of an amplification loop allowing ATP-dependent ATP release. Importantly using cytochalasin $\mathrm{D}$, we show that ATP release requires particle phagocytosis as mature IL-1 $\beta$ production. Importantly, ATP-or nigericin-induced IL-1 $\beta$ secretion was not affected in the presence of cytochalasin $D$, confirming that cytochalasin D acts on particle phagocytosis but not P2X7 receptor and/or pannexin channel activities. Our results do not rule out previous finding showing that phagolysosomal acidification and disruption with cathepsin $\mathrm{B}$ release are required for NIrp3 inflammasome activation. ${ }^{1,2}$ We confirm the involvement of cysteine cathepsins in the production of mature IL-1 $\beta$ but for the first time we demonstrate that these proteases including cathepsin B play a role in ATP release, suggesting they may be involved in channel maturation and/or opening processes upstream of NIrp3 inflammasome assembly. In an attempt to summarize our data, we propose the model presented in Figure 7.

We show that phagocytosis of particulate activators induces membrane permeabilization through membrane channel opening with sequential ATP release and purinergic signaling leading to inflammasome activation. This model provides a link between particle internalization- and membrane permeabilization-mediated NIrp3 inflammasome activation since particulate molecules and eATP are still considered as two completely independent ways to activate the NIrp3 inflammasome. We show here that ATP release and purinergic signaling is a step of crystal-induced inflammasome stimulation. This is of clear account in regards to extensive work showing that eATP could act as a danger signals released in numerous situations.

\section{Materials and Methods}

Reagents. MSU (average length $14.02 \mu \mathrm{M} \pm 7.72$ ) and allopurinol crystals (prepared as described ${ }^{38}$ ) silica (Dr. F Huaux, Bruxelles, Belgium) and Alum (Imject Alum, Thermo Scientific, Rockford, IL, USA) were used at 125-500 $\mu \mathrm{g} / \mathrm{ml}$ as mentioned. Particles were sonicated $30 \mathrm{~min}$ prior use.

A740003 is a gift from Dr. F Rassendren (Montpellier, France). ATP, ATP $\gamma$ S, ADP, ADP $\beta$ S, MeATP, UTP, nigericin, A438079, oATP, CBX, FFA, bafilomycin $A 1$, pepstatin A, ARL67156 and apyrase grade VII were from Sigma (St. Quentin Fallavier, France), Ca074-Me, E64d and cytochalasin D from Calbiochem Merck (Fontenay sous bois, France).

Mouse bone marrow-derived cells culture and stimulation. Deficient mice and methods used to prepare primary BMDM and BMDC are described in Supplementary Information. BMDM and BMDC were plated in 96-well microculture plates $\left(2 \times 10^{5} \mathrm{cell} / \mathrm{s} / \mathrm{wll}\right)$ and primed $3 \mathrm{~h}$ with $100 \mathrm{ng} / \mathrm{ml}$ ultrapure 


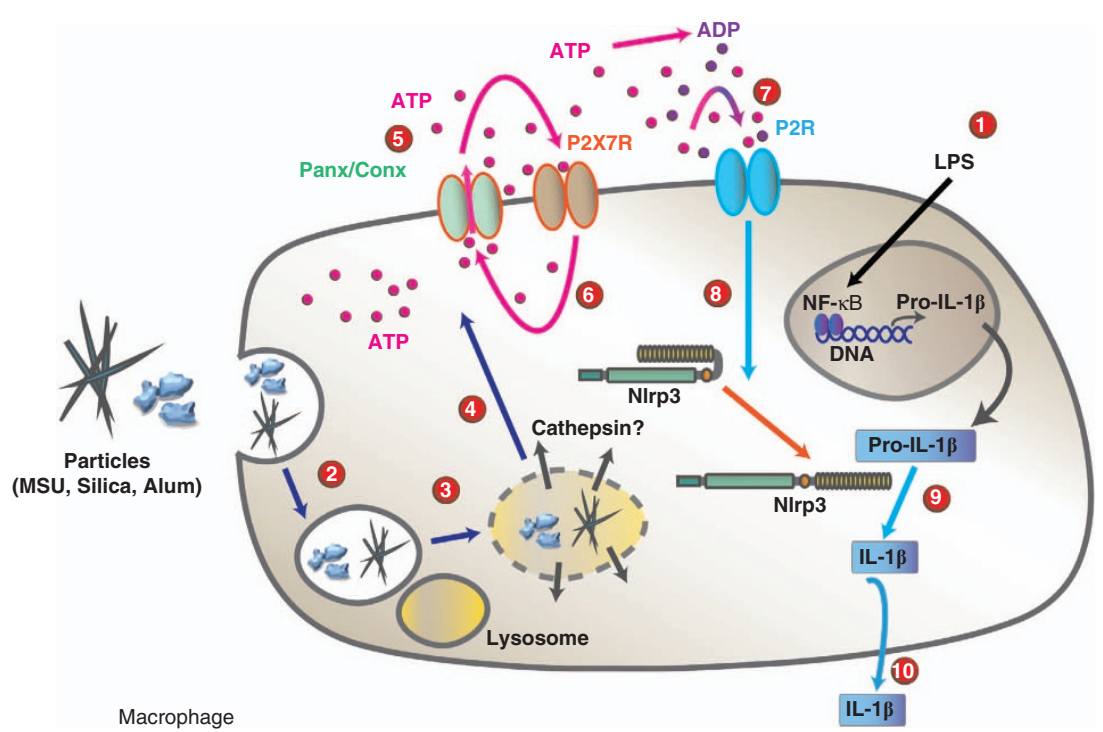

Figure 7 Schematic diagram illustrating the specific cascade and signaling pathway in LPS-primed macrophages stimulated with MSU, silica or Alum salt crystals. LPS priming induces transcription of pro-IL-1 $\beta$ gene and other genes in the nucleus upon activation of the transcription factor NF $\kappa$ B and subsequent production of pro-IL-1 $\beta$ protein in the cytosol (1). Particle internalization (2), fusion to lysosome (3) and further phagolysosome destablization may lead to cathepsin leakage (4), which precedes pannexin/ connexin (Panx/Conx) hemichannel and purinergic signaling dependent intracellular ATP release (5). Extracellular ATP may act through P2X7 receptor to amplify ATP release in a P2X7 receptor dependent way (6). ATP or its derived degradation products such as ADP, generated by ecto-endonucleases, act through an autocrine loop on other purinergic receptor P2X and/or P2Y receptors (7) leading to Nlrp3 receptor activation (8). This allows inflammasome complex formation and maturation of pro-IL-1 $\beta$ to IL-1 $\beta$ production (9) and IL-1 $\beta$ secretion (10)

LPS (Escherichia coli, serotype O111.B4, Invivogen, Toulouse, France) then washed and stimulated by particles and listed compounds for $6 \mathrm{~h}$ or $30-45 \mathrm{~min}$ with ATP (5 mM). Supernatants were collected and IL-1 $\beta$ or TNF- $\alpha$ cytokines were assayed by ELISA assay.

Human monocytes/macrophages THP1 cells culture and stimulation. THP1 cells were cultured in RPMI, 10\% FCS (Hyclone, Cramlington, UK), penicillin (100 U/ml, Invitrogen, Illkirch, France) and streptomycin $(100 \mu \mathrm{g} / \mathrm{ml}$, Invitrogen). For experiments, THP-1 cells were differentiated $3 \mathrm{~h}$ with $0.5 \mu \mathrm{M}$ phorbol 12-myristate 13-acetate (Sigma Aldrich, Saint Louis, MO, USA), washed and overnight plated $\left(2 \times 10^{5} \mathrm{cell} / \mathrm{sell}\right)$. Cells were stimulated for indicated time, supernatant collected for concomitant ATP measurement and/or further IL-1 $\beta$ quantification.

ATP measurement. eATP in cell culture supernatant was quantified using ATP Lite One-Step kit (Perkin-Elmer, Waltham, MA, USA). Quick centrifugation of the plates was performed to avoid any cell debris contamination. Luminescence was measured with a luminometer (Mithras, Berthold Technologies, Bad Wildbad, Germany) and ATP concentration determined using standard curve allowed samples quantification.

Cytokine measurement by ELISA. IL- $1 \beta$ and TNF- $\alpha$ levels in cell supernatant were determined using ELISA assay kits (R\&D Systems, Minneapolis, MN, USA) according to the manufacturer's instructions.

Immunoblotting. Supernatants were collected and stored for further analysis. Cells were washed with cold PBS and scraped in lysis buffer solution $(150 \mathrm{mM}$ $\mathrm{NaCl}, 10 \mathrm{mM}$ Tris, pH 8, $1 \mathrm{mM}$ EDTA, 0.2\% SDS and 1\% Nonidet P-40) supplemented with a protease inhibitor cocktail $(1 \%)$ and pefabloc $(0.1 \mathrm{mg} / \mathrm{ml})$ (Roche Applied Science, Meylan, France). Lysis extracts were sonicated and after centrifugation, supernatants were collected and protein content measured (DC protein assay, Bio-Rad, Munich, Germany). Proteins were denatured by boiling $\left(95^{\circ} \mathrm{C}, 5 \mathrm{~min}\right)$, separated by SDS-PAGE and transferred to nitrocellulose membranes. The membranes were immunoblotted with primary goat anti-IL-1 $\beta$ antibody (Sigma Aldrich) and proteins detected with appropriate secondary rabbit polyclonal antibody (Sigma Aldrich) conjugated to horseradish peroxidase followed by enhanced chemiluminescence (ECL; Fisher, Illkirch, France).
Statistics. Statistical evaluation of differences between the experimental groups was determined by Mann-Whitney test using Prism software (La Jolla, CA, USA). $P$-values of $<0.05$ were considered statistically significant.

\section{Conflict of Interest}

The authors declare no conflict of interest.

Acknowledgements. We are grateful to the support of the 'Agence National de Recherche' (France) and the 'Conseil Général du Loiret' (France). We thank Dr. B Robaye (IRIBHM, Gosselies, Belgium) for the kind gift of P2Y2 receptor-deficient mice and Dr. Amir Yazdi (Tuebingen, Germany) for the gift of human monocyte/ macrophage THP-1 cell line. We are grateful to Léa Brault for mice breeding management and François Erard and Valérie Quesniaux for scientific discussion and to David Kugler (NIH/NIAID, Bethesda, MD, USA) for technical assistance in the illustration. This study grant was supported by the French «Agence Nationale de Recherche» and the «Conseil Général du Loiret».

1. Dostert C, Petrilli V, Van Bruggen R, Steele C, Mossman BT, Tschopp J. Innate immune activation through Nalp3 inflammasome sensing of asbestos and silica. Science 2008; 320 : 674-677.

2. Hornung V, Bauernfeind F, Halle A, Samstad EO, Kono H, Rock KL et al. Silica crystals and aluminum salts activate the NALP3 inflammasome through phagosomal destabilization. Nat Immunol 2008; 14: 1256-1263.

3. Eisenbarth SC, Colegio OR, O'Connor W, Sutterwala FS, Flavell RA. Crucial role for the Nalp3 inflammasome in the immunostimulatory properties of aluminium adjuvants. Nature 2008; 453: 1122-1126.

4. Zhou R, Tardivel A, Thorens B, Choi I, Tschopp J. Thioredoxin-interacting protein links oxidative stress to inflammasome activation. Nat Immunol 2010; 11: 136-140.

5. Duewell P, Kono H, Rayner KJ, Sirois CM, Vladimer G, Bauernfeind FG et al. NLRP3 inflammasomes are required for atherogenesis and activated by cholesterol crystals. Nature 2010; 464: 1357-1361.

6. Halle A, Hornung V, Petzold GC, Stewart CR, Monks BG, Reinheckel T et al. The NALP3 inflammasome is involved in the innate immune response to amyloid-beta. Nat Immunol 2008; 9: 857-865.

7. Babelova A, Moreth K, Tsalastra-Greul W, Zeng-Brouwers J, Eickelberg O, Young MF et al. Biglycan: a danger signal that activates the NLRP3 inflammasome via toll-like and P2X receptors. J Biol Chem 2009; 284: 24035-24048. 
8. Mariathasan S, Weiss DS, Newton K, McBride J, O'Rourke K, Roose-Girma M et al. Cryopyrin activates the inflammasome in response to toxins and ATP. Nature 2006; 440: 228-232.

9. Martinon F, Petrilli V, Mayor A, Tardivel A, Tschopp J. Gout-associated uric acid crystals activate the NALP3 inflammasome. Nature 2006; 440: 237-241.

10. Cassel SL, Joly S, Sutterwala FS. The NLRP3 inflammasome: a sensor of immune danger signals. Semin Immunol 2009; 21: 194-198.

11. Pelegrin P, Surprenant A. Pannexin-1 couples to maitotoxin- and nigericin-induced interleukin-1beta release through a dye uptake-independent pathway. J Biol Chem 2007; 282: 2386-2394

12. Praetorius HA, Leipziger J. ATP release from non-excitable cells. Purinergic Signal 2009; 5: 433-446.

13. Lazarowski ER, Boucher RC, Harden TK. Mechanisms of release of nucleotides and integration of their action as P2X- and P2Y-receptor activating molecules. Mol Pharmacol 2003; 64: 785-795

14. Yegutkin GG. Nucleotide- and nucleoside-converting ectoenzymes: important modulators of purinergic signalling cascade. Biochim Biophys Acta 2008; 1783: 673-694.

15. Iyer SS, Pulskens WP, Sadler JJ, Butter LM, Teske GJ, Ulland TK et al. Necrotic cells trigger a sterile inflammatory response through the Nirp3 inflammasome. Proc Natl Acad Sci USA 2009; 106: 20388-20393.

16. Riteau N, Gasse P, Fauconnier L, Gombault A, Couegnat M, Fick L et al. Extracellular ATP is a danger signal activating P2X7 receptor in lung inflammation and fibrosis. Am J Respir Crit Care Med 2010; 182: 774-783.

17. Okada SF, Nicholas RA, Kreda SM, Lazarowski ER, Boucher RC. Physiological regulation of ATP release at the apical surface of human airway epithelia. J Biol Chem 2006; 281: 22992-23002

18. Joseph SM, Buchakjian MR, Dubyak GR. Colocalization of ATP release sites and ectoATPase activity at the extracellular surface of human astrocytes. J Biol Chem 2003; 278: 23331-23342.

19. Bao L, Locovei S, Dahl G. Pannexin membrane channels are mechanosensitive conduits for ATP. FEBS Lett 2004; 572: 65-68.

20. Harris AL. Connexin channel permeability to cytoplasmic molecules. Prog Biophys Mol Biol 2007; 94: 120-143.

21. Orellana JA, Froger N, Ezan P, Jiang JX, Bennett MV, Naus CC et al. ATP and glutamate released via astroglial connexin 43 hemichannels mediate neuronal death through activation of pannexin 1 hemichannels. J Neurochem 2011; 118: 826-840.

22. Scemes E, Spray DC, Meda P. Connexins, pannexins, innexins: novel roles of 'hemi-channels'. Pflugers Arch 2009; 457: 1207-1226.

23. King BF. Novel P2X7 receptor antagonists ease the pain. Br J Pharmacol 2007; 151: 565-567.

24. Chen $Y$, Corriden R, Inoue $Y$, Yip L, Hashiguchi N, Zinkernagel A et al. ATP release guides neutrophil chemotaxis via P2Y2 and A3 receptors. Science 2006; 314: 1792-1795.
25. Perregaux D, Gabel CA. Interleukin-1 beta maturation and release in response to ATP and nigericin. Evidence that potassium depletion mediated by these agents is a necessary and common feature of their activity. J Biol Chem 1994; 269: 15195-15203.

26. Di Virgilio F. Liaisons dangereuses: P2X(7) and the inflammasome. Trends Pharmacol Sci 2007; 28: 465-472.

27. Ferrari D, Pizzirani $C$, Adinolfi E, Lemoli RM, Curti A, Idzko M et al. The P2X7 receptor: a key player in IL-1 processing and release. J Immunol 2006; 176: 3877-3883.

28. Netea MG, Nold-Petry CA, Nold MF, Joosten LA, Opitz B, van der Meer JH et al Differential requirement for the activation of the inflammasome for processing and release of IL-1beta in monocytes and macrophages. Blood 2009; 113: 2324-2335.

29. Piccini A, Carta S, Tassi S, Lasiglie D, Fossati G, Rubartelli A. ATP is released by monocytes stimulated with pathogen-sensing receptor ligands and induces IL-1beta and IL-18 secretion in an autocrine way. Proc Natl Acad Sci USA 2008; 105: 8067-8072.

30. Sanz JM, Chiozzi P, Ferrari D, Colaianna M, Idzko M, Falzoni S et al. Activation of microglia by amyloid \{beta\} requires P2X7 receptor expression. J Immunol 2009; 182: 4378-4385.

31. Di Virgilio F, Borea PA, Illes P. P2 receptors meet the immune system. Trends Pharmacol Sci 2001; 22: 5-7.

32. Bours MJ, Swennen EL, Di Virgilio F, Cronstein BN, Dagnelie PC. Adenosine 5'triphosphate and adenosine as endogenous signaling molecules in immunity and inflammation. Pharmacol Ther 2006; 112: 358-404.

33. Brough D, Pelegrin P, Rothwell NJ. Pannexin-1-dependent caspase-1 activation and secretion of IL-1beta is regulated by zinc. Eur J Immunol 2009; 39: 352-358.

34. Franchi L, Kanneganti TD, Dubyak GR, Nunez G. Differential requirement of P2X7 receptor and intracellular $\mathrm{K}+$ for caspase- 1 activation induced by intracellular and extracellular bacteria. J Biol Chem 2007; 282: 18810-18818.

35. Pelegrin $P$, Surprenant A. Pannexin-1 mediates large pore formation and interleukin-1beta release by the ATP-gated P2X7 receptor. Embo J 2006; 25: 5071-5082.

36. Qu Y, Misaghi S, Newton K, Gilmour LL, Louie S, Cupp JE et al. Pannexin-1 is required for ATP release during apoptosis but not for inflammasome activation. J Immunol 2011; 186: 6553-6561.

37. Chekeni FB, Elliott MR, Sandilos JK, Walk SF, Kinchen JM, Lazarowski ER et al. Pannexin 1 channels mediate 'find-me' signal release and membrane permeability during apoptosis. Nature 2010; 467: 863-867.

38. Gasse P, Riteau N, Charron S, Girre S, Fick L, Petrilli V et al. Uric acid is a danger signal activating NALP3 inflammasome in lung injury inflammation and fibrosis. Am $\mathrm{J}$ Respir Crit Care Med 2009; 179: 903-913.

Cell Death and Disease is an open-access journal published by Nature Publishing Group. This work is licensed under the Creative Commons Attribution-NonCommercial-No Derivative Works 3.0 Unported License. To view a copy of this license, visit http://creativecommons.org/licenses/by-nc-nd/3.0/

Supplementary Information accompanies the paper on Cell Death and Disease website (http://www.nature.com/cddis) 